\title{
THE EVOLUTION OF THE TOWNHOUSE AND ITS ROLE IN CREATING SUSTAINABLE COMMUNITIES
}

\author{
T.J. BARTUSKA \\ School of Design \& Construction, Washington State University, USA.
}

\begin{abstract}
The townhouse has evolved over more than a 1000 years and is a highly valued living environment in Europe and throughout the western World. It is a sustainable building prototype and has effectively responded to environmental, social, cultural and economic forces in society. Townhouses have adapted to these ecological and dynamic changes in both rural and urban settlements, contributing to a sense of community while providing privacy for those fortunate enough to live within its walls. The townhouse is responsive to design with "nature" integrating both human nature and natural systems. The compact, common wall construction is inherently more economical, energy efficient and can create an ideal density for walkable and transit-oriented communities.

The townhouse can also be referred to as terrace or row house. The townhouse is the preferred term because it references both town and home or the important dual interdependency between community and privacy. The townhouse's public realm, the "fronts", can interact in a friendly, complementary way with the community street or help define a communal space. The "backs" provide outdoor space for private activities and gardening. Their architecture can be responsive to any regional or environmental context and help shape the composite character of its sense of place, yet establishing variety, human scale and individual identity.

The long evolutionary life of the townhouse is full of rich and rewarding lessons. Its longevity transcends various architectural periods; is an adaptable, time tested or timeless building prototype and offers important principles for contemporary architecture and urbanism. This essay will trace the townhouse's dynamic and ecological (ecodynamic) development throughout the ages and defines useful design qualities and planning principles that are relevant to society today as we secure a sustainable future, locally as well as throughout the world.

Keywords: Acre, community, ecodynamic, ecological design and planning, green architecture, housing sustainability, townhouse, urbanism.
\end{abstract}

\section{IDENTIFYING DESIGN QUALITIES OF HOME AND PLACE}

The townhouse establishes a strong sense of identity of home and place in a variety of settings. It also has been able to adapt to changing historic periods, settlement patterns and various regional qualities. First, let us explore the historic development of the townhouse and then ponder the implications to contemporary design, planning and urban sustainability.

\subsection{Adaptability to land and changing settlement patterns}

Over the 1000 years of development, the townhouse has adapted too many settlement patterns, both rural and urban. It has evolved from a fascinating and poorly understood (some would say confusing) system of land measurement - the acre. The acre is a very old, organic system, which Rasmussen [1], a prominent Danish architect and scholar, states that this ancient measurement is "literally ... at the grass roots of planning." Understanding this ancient land measurement clarifies why the mile and the acre have such seemingly strange dimensions. The mile is 5280 feet in length and the acre has an area of 43,560 square feet or a square area of 208.71 feet on a side. Why are these numbers so strange yet profound as an effective measurement system for land subdivisions?

Rasmussen continues to clarify this organic planning tools: "The old English measurements were, nevertheless, not so foolish as they now appear to us because they were used in quite a different way, namely, as a tool to mark out the right dimensions of land and buildings. Acre is an exceedingly old 


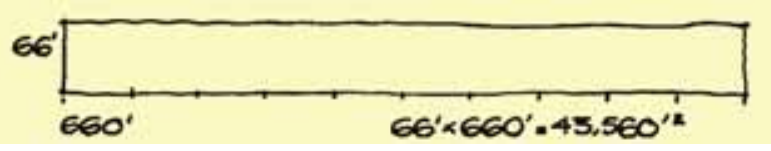

Figure 1: The original size of an acre $\left(66^{\prime} \times 660^{\prime}\right)$.

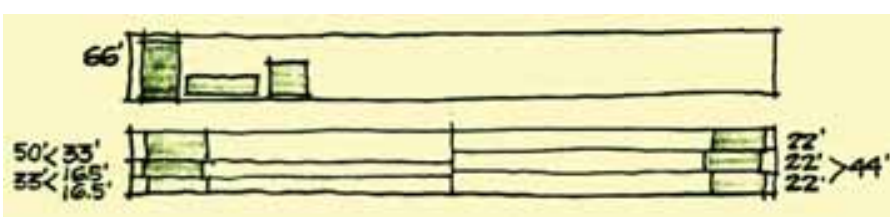

Figure 2: The original acre and its subdivisions.

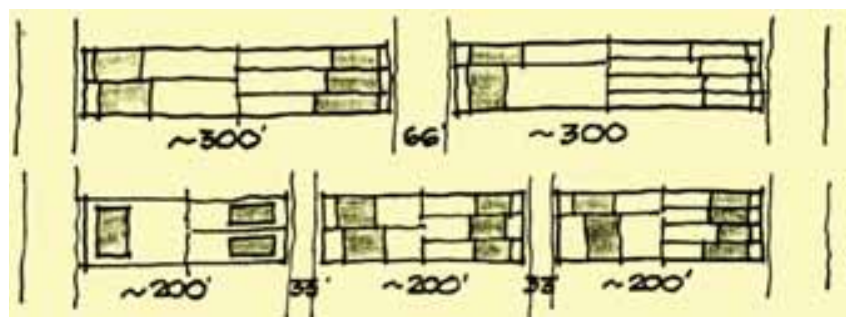

Figure 3: The original acre subdivided with streets.

word meaning a field of arable or pasture land. As a measurement, it was first defined as the amount of land a yoke of oxen could plough in a day. [Also, if effectively used, one acre can be enough land to supply most of the agricultural needs for a family.] It was not supposed to be a regular square but a very oblong rectangle (Fig. 1). Its length was ... a furrow (660 feet [or 1/8 of a mile]) and its width was 1 chain (66 feet). When the surveyor wanted to mark out an acre in the field, he would use a 66-foot long chain. It can literally be said that here we are at the grass roots of planning. When shorter lengths were to be marked out, a rod was used. A rod was 16.5 feet. Accordingly, there were four rods to a chain. At that time, in the London area, a normal worker's house had a frontage of 1 rod."

As families or villages grew, these land dimensions were shared and subdivided as settlement densified (Fig. 2). The acre was subdivided in both the directions. The $66^{\prime}$ (feet) dimension could create $2-33^{\prime}$ partials, $3-22^{\prime}$ or $4-16.5^{\prime}$ units or other combinations $\left(16.5^{\prime}\right.$ and $33^{\prime}$ units approximate $\left.50^{\prime}\right)$.

The subdivisions are compatible to many successful contemporary housing developments. Today, a $16.5^{\prime}$ rod approximates the minimum width of a townhouse (4 units within the original acre's $66^{\prime}$ frontage). Townhouses at $22^{\prime}$ wide ( 3 units that fit the $66^{\prime}$ chain) are a more generous size for a townhouse. Two units at $33^{\prime}$ are a common width for a large, very spacious urban house, attached or detached. Even today, 25, 35'and 50' are common dimensions used in urban and suburban land subdivisions and $65^{\prime}$ is the minimum width commonly found in suburb developments.

The 660' direction has similar effective subdivisions. Taking away land for streets, one finds 300 , 200,150 and $100^{\prime}$ subdivisions and these are very common dimensions used for property subdivisions and urban blocks (Fig. 3). The adaptability and flexibility is an important quality to the changing dynamics of most livable community and urban environments today. Examples of the way the townhouse and the acre have adapted to various community and urban forms are illustrated in the Medieval segment of this essay. 


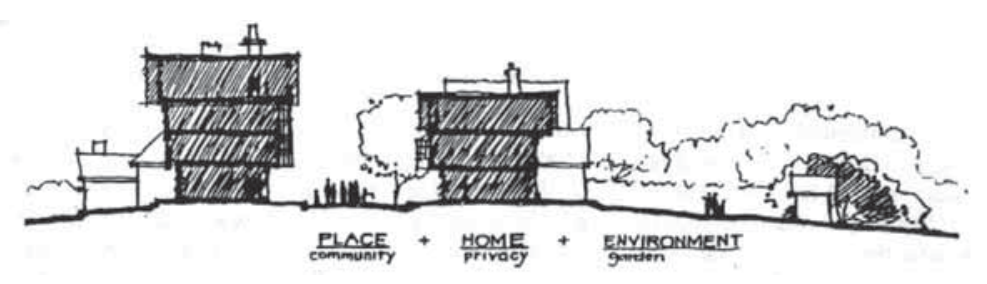

Figure 4: The Medieval section: place + home + environment.

\subsection{Defining home and place: an ecological paradigm}

Over the centuries, the townhouse has adapted to various community patterns and can create an expressive character to the "townscape" of the public realm. To gain a clearer understanding of how this housing form adapts to the community and privacy issues of home and place, it is important to understand not only how the acre can subdivide into plan but also how it develops into section (Fig. 4).

First of all, the longitudinal section effectively connects home to place or the privacy needs of a dwelling to community. Besides home to place, it also connects home to environment and helps establish a gardening tradition that is important in western societies (especially prominent in England).

The townhouse section interrelates these three primary elements: place (community public realm), home (privacy) and environment (private gardens). It interconnects the individual unit and its architecture to its community context and the natural environment. This ecological model parallels many others. In the latter part of the 19th century, Ebenezer Howard [2], founder of the Garden Cities Movement, introduced and used a similar diagram (The Three Magnets) and suggested that the marriage between the qualities of town and country is an ideal model for design and planning. The Medieval section represents the best of what many authors propose when studying and defining community and privacy. In contemporary terms, it is an inclusive ecological paradigm that addresses human-environmental interrelationships of home, place and environment.

\subsection{Effectiveness: an evolution towards an optimum density}

In many ways, the townhouse develops an optimum density for both housing and community. Their narrow frontage efficiently reduces the extensive costs of auto-driven sprawl (infrastructure, land, energy, air and water pollution, loss of agriculture and human lives, etc.) [3]. The townhouse net density can vary between 10 and 24 dwelling units (DU) per acre (25-60 DU per hectare). A density of 12-15 DU/A is a minimum level that makes many community services, including neighbourhood schools and public transit, accessible and cost-effective. Furthermore, their compact, common wall construction is inherently more economical, energy efficient and sustainable. All these factors celebrate a sense of community at the urban, village and/or neighbourhood levels by establishing an animated pedestrian environment for walkable and transit-oriented communities where many of these community services are accessible and become an important part of personal, family and community life.

\section{PLACE MAKING: REGIONALISM AND CULTURAL IDENTITY}

At the largest scale, the townhouse can also embody a regional identity. It accomplishes this by adapting to and expressing various regional characteristics (climate and material resources). The townhouse common wall construction responds best to temperate and cold northern climates. 


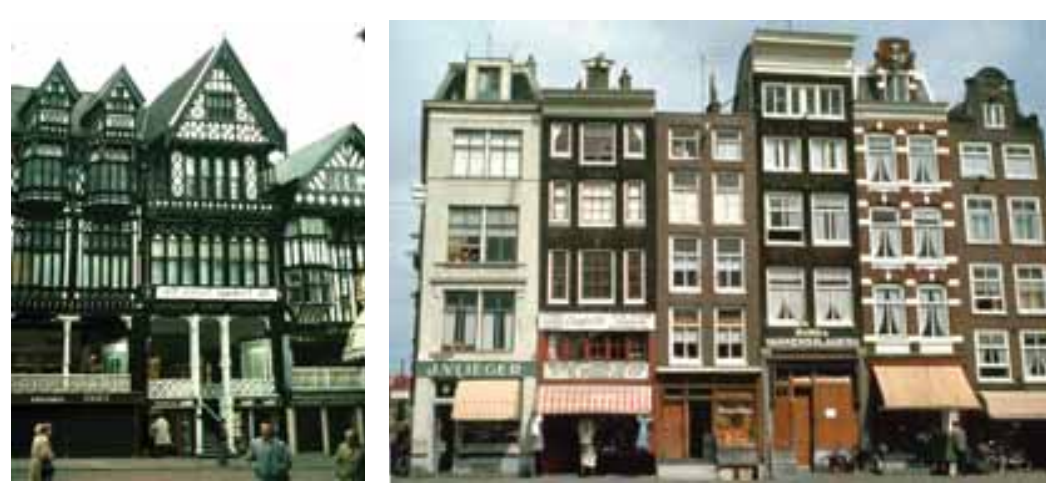

Figure 5: Cultural expression: Chester, England and Amsterdam, Holland.

Like almost all buildings, it is most efficient with north-south orientation. East-west orientation can work well when the units have effective summer shading and its section allows for effective cross and stacked ventilation in the warmer seasons.

The townhouse can also effectively express various cultural patterns (Fig. 5). The continuous massing defines the community space and its architectural expression can develop effective surveillance especially with bay windows that allow the observation of activities up and down the public realm. On an active commercial street, the units can adapt to desirable mixed-use concepts as public floors can be designed for shops and offices with housing above.

Culturally, townhouses have also expressed various common regional, even national qualities [4]. As illustrated above, one can visually identify and therefore appreciate the indigenous qualities of the regional and/or national characteristics because they have been developed within a unifying system of land subdivisions and are expressed in a common palette of regional materials, details and construction methods.

As the cultural and environmental context for the townhouse changes, its architecture has been able to express these unique indigenous characteristics and thereby forms a meaningful architectural language. Their incremental growth can adapt to a variety of land topographic characteristics. This adaptability establishes an effective identity of home and place within a region's built and natural environment.

\section{ADAPTABILITY TO TIME AND VARIOUS HISTORIC PERIODS}

The townhouse has also adapted to changes in architectural and urban design paradigms (styles) - a necessary quality to be successful and sustainable. The following brief chronological sketch will show the adaptability of the townhouse and how it relates to various historic periods and their resultant informal and formal settlement patterns.

\subsection{Informal medieval developments}

As discussed, the townhouse has effectively developed in both rural to urban settlement patterns. Hoskins [5] identifies three generic types in his classic study The Making of the English Landscape. The three settlement types are defined by their relationships to: (A) Linear along a street; (B) Focused around a green, market or natural resource and (C) Mixture of A and B or scattered and non-focused (Fig. 6). Within all the above patterns, the townhouse in both plan and section has been able to 
effectively adapt and establish a sense of home and place. The Medieval developments are decidedly informal by adapting too many curvilinear, non-regular or organic street patterns. The informal character gives the Medieval built form an animated charm and character (Fig. 7).

As clarified above, the Medieval settlement patterns in plan and section can increase in density by increasing its floor levels, filling in back gardens and changing its functions. For commercial development, these townhouses have also been able to adapt to shops and offices with effectiveness (Fig. 8). The variety of the sizes allows for a useful diversity of activities. The townhouse has also been able to adapt to corner locations for commercial developments. Because the corner locations tend to lose their back garden, these evolutionary changes are logical and appropriate for commercial enterprises. The units have also created quality commercial environments at the street and upper-level arcaded development. These mixed use townhouse developments are very popular to the local people, retain a sense of focus and identity of a place, and have special attraction for visitors (tourism).

The animated Medieval townscapes have many other qualities. The streets have a positive enclosure, establishing a wonderful sense of place [7]. The informal settlement patterns establish a delightful continuum of sequential experiences, well documented by Cullen [8] and Lloyd [9]. The original land module and subdivisions give the street wall an expressive variety within a unifying module, frame and rhythm. The architecture, through its adaptability or a process of piecemeal growth, achieves an expression of variety in unity, an appropriate human scale and richness in construction details.

When regional materials and construction methods are used, the buildings are expressed in a unified palette of materials, textures and forms that bond these developments together and create a stronger community identity (Fig. 9).

A

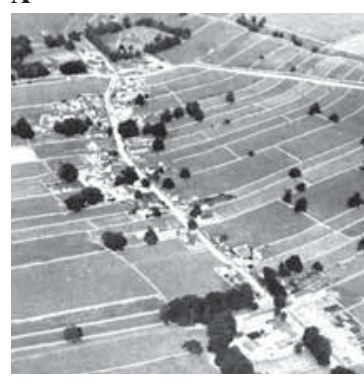

B

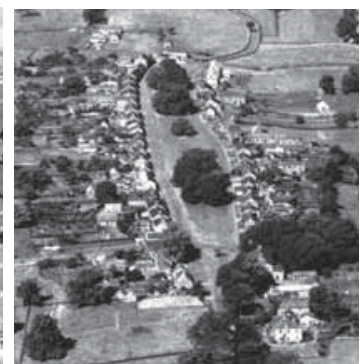

C

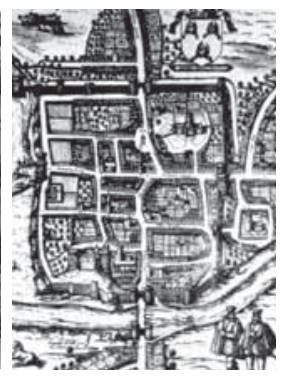

Figure 6: Village forms (A) linear, (B) focused and (C) mixture of A and B [6].
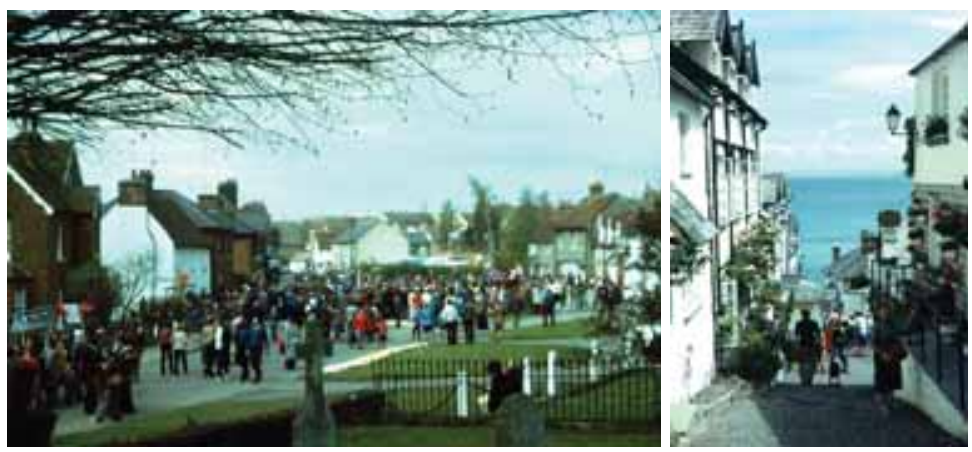

Figure 7: Residential streets of varying scale and sense of enclosure. 


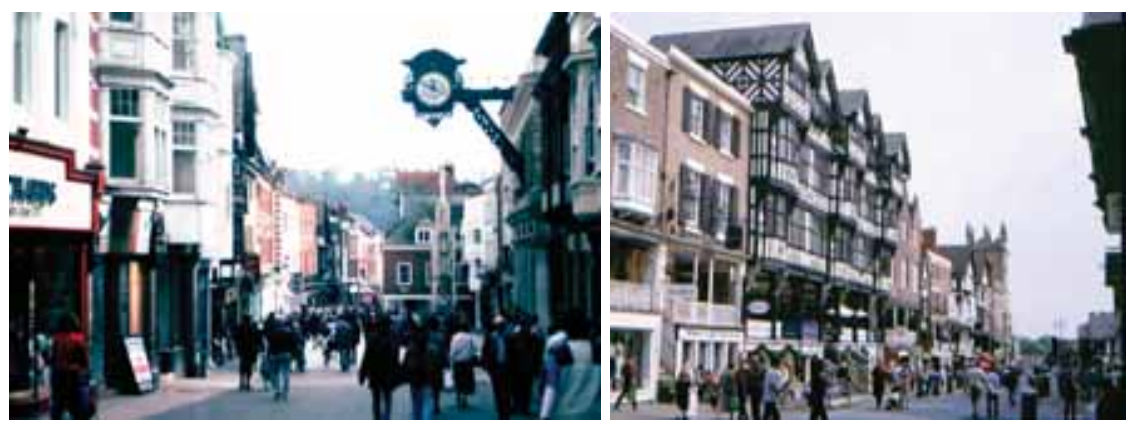

Figure 8: Urban streets of varying scale and sense of enclosure.
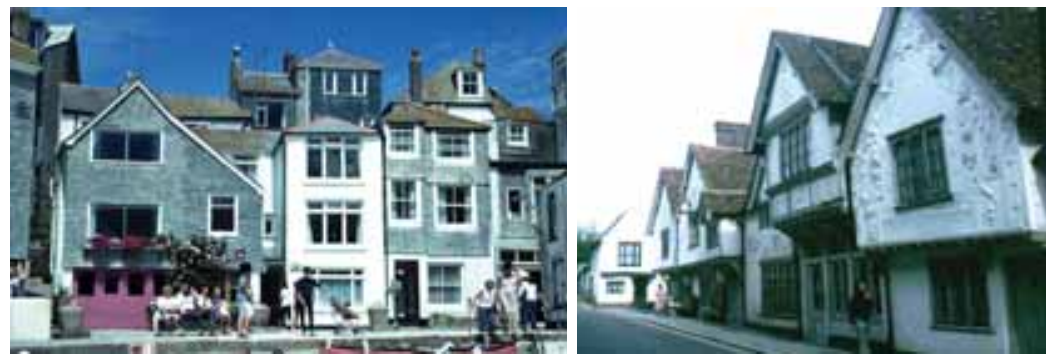

Figure 9: Variety in unity: villages with a playful palette of compatible forms and/or regional materials.
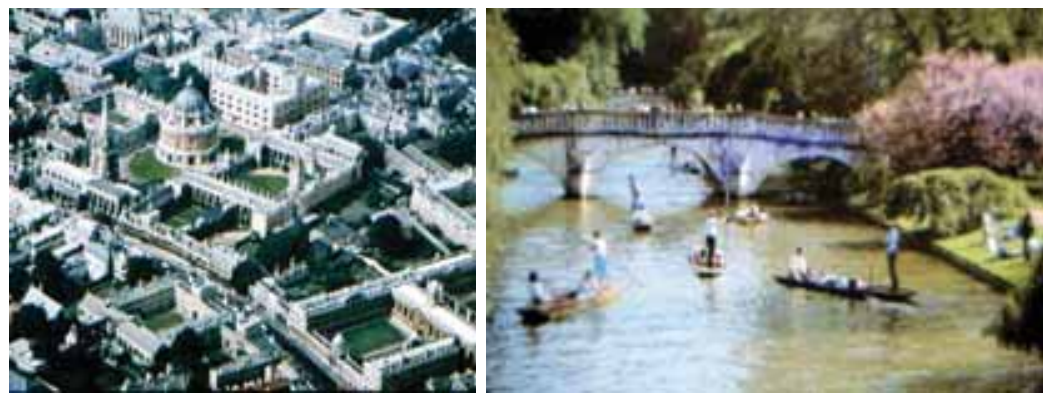

Figure 10: Medieval urbanism (Oxford) and the quiet backs (Cambridge).

Because the units relate to a public community street or space, they help protect street safety through surveillance, the diversity of use and a sense of 24-hour life - important principles well defined by Jacobs [10] and Newman [11].

In Medieval developments, the backs were used for private gardens (food and/or proprietor activities). The backs have also adapted to changing use and have accommodated increased density. In the transformation to commercial use, the backs have become service and work yards, recreational garden courts, even parking. The original developments of the university and their colleges evolved from these adaptable Medieval patterns as expressed in the delightful college environments of both Cambridge and Oxford (Fig. 10). The colleges are formed in the back court yards of these settlement patterns. Collectively, the backs have also allowed for significant space for contemporary expansion. 

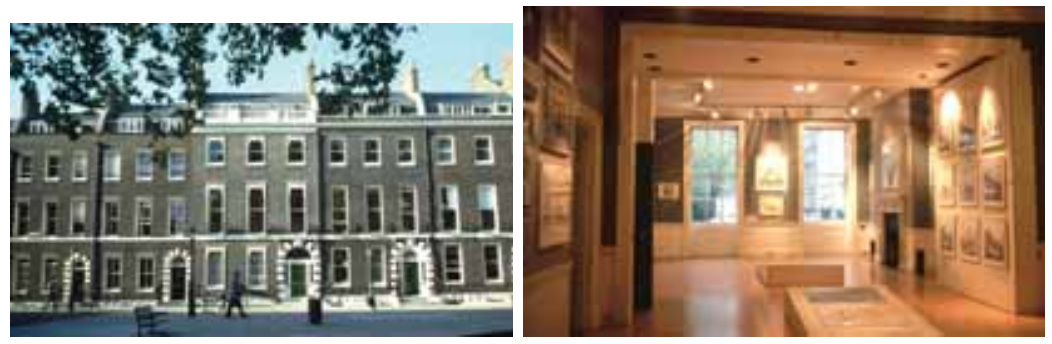

Figure 11: Bedford Square townhouse exterior and interior (changed from a residence to the London Architecture Association).

\subsection{The formal Renaissance developments}

During the 17th and 18th century, new developments shifted from the more informal, organic Medieval patterns to the more fashionable formal geometric patterns promoted during the Renaissance. Although the stylistic tenets changed dramatically, the living patterns, as related to the community and privacy, remain similar. The best developments retained the townhouse section and established the same interconnection between place, home and environment (gardens). In a general sense, the urban patterns were similar to Medieval arrangements as their more formal geometric layouts relate to: (A) linear (Street); (B) focused (Square, Park or Green) and (C) mixture (combination of A and B). Whereas the major gardens in the Medieval townscape were in the private backs, the major garden concepts in the Renaissance were composed in the public front of these formally composed schemes. The backs were minimised for service functions.

Rasmussen [1] states that the Renaissance or Georgian townhouse is one of the finest contributions to urban living [even though the precedent for home and place evolved some five centuries before]. The formal qualities of this period of development are more static in time and do not permit as much external change even though internally the functions have changed dramatically (Fig. 11).

\subsection{Modernism: an unfortunate break from tradition}

In the 20th century, high-rise housing developments proposed by leading Modernists were built throughout the world. They solved the problems of increased urban density but dramatically compromised the sense of home and place for the average family. Also, during this time, the extensive suburban developments, so popular in the United States, have established a comfortable sense of home but are hopeless in establishing enough density to create a composite sense of community. The auto-driven low-density developments are extremely inefficient and very wasteful of human and environmental resources (in urban, suburban and rural settings) [3].

Besides high rise and suburban development of this period, there were other significant and successful developments. In England, the Garden Cities Movement and 1946 Greater London Plan are not well known in architectural circles but world renown in terms of effective regional, urban and community planning. The new towns and urban infill strategies achieved higher, even an optimum density, in low-rise environments by the extensive use of the townhouse. The combination created more comfortable, affordable and efficient residential and community developments for the lower to average income family than the high-rise and suburban alternatives. 


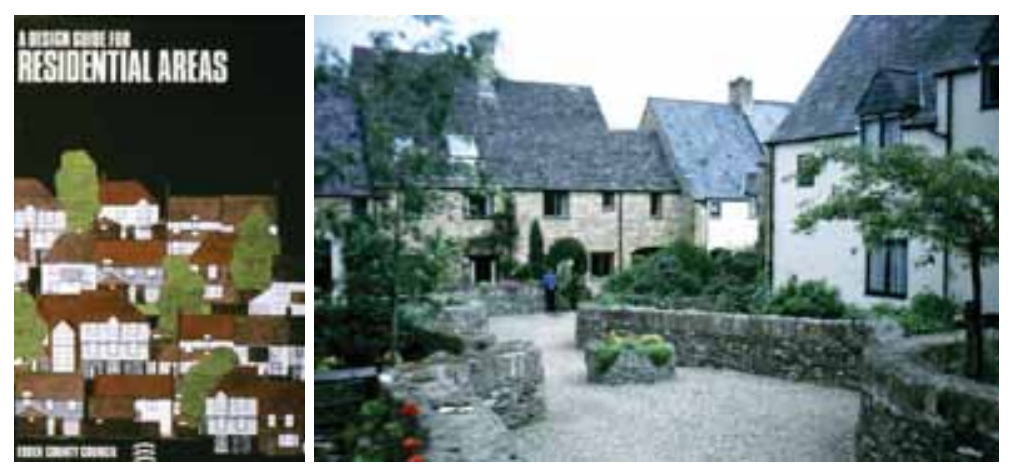

Figure 12: Essex Design Guidelines: policy and example.

\subsection{Contemporary developments}

Currently, there is a dramatic return to the patterns and principles established long ago by the Medieval builders. Ralph Erskine has been very successful in developing housing projects that are based upon indigenous ecological patterns defined by citizen participation (Eaglestone, Milton Keynes; Byker, Newcastle and London's Sustainable Village). Erskine's projects are decidedly informal and are based upon a clear understanding of the successful time-tested patterns of families living on the ground. They develop a strong sense of home, place and environment through carefully defining territoriality, defensible space and surveillance - all critical concepts in creating successful residential communities. They are highly favoured by their local inhabitants.

Another major influence in England was the Essex Design Guide (Fig. 12) [12]. The document establishes recommended guidelines for residential developments in the County of Essex. Other municipalities have similar guidelines or extensive design and planning review procedures to guide new developments. The Essex policies are based upon a reaffirmation of the timeless Vernacular traditions in shaping home and place. Primarily, the guidelines rediscover the patterns of the Medieval townscape and the townhouse. Like all design guidelines, they can be somewhat controversial and seemingly a bit limiting to the creative designer. On the other hand, the quality of most new housing developments in Essex and throughout England that post-date 1975 is remarkably successful. They fit the English townscape and are valued by the local people.

Today, the retention and reanimation of the centrality of cities (preventing auto-driven sprawl and scattered commercial development) is critically important to the sustainability of our humanenvironmental needs and our local and global civilisation. Consequently, new commercial and residential growth is best within the existing city centers, reestablishing human scale and townscape qualities of the Medieval builders. This critical concept of clustered, transit-oriented development is reconfirmed in England's current governmental guidelines for the 21st century [13]. They are significant in formulating a profound national policy for sustainable development.

\section{CONCLUSION: A SEARCH FOR A USEFUL AND SUSTAINABLE DESIGN PARADIGM}

Tracing through the above developments has emphasised the continuity of a theme as conveyed by the townhouse. Because the theme transcends stylistic paradigms, it seems important to clarify what these developments mean to 21 st century designers and planners. 
It is useful to discuss the relevancy of stylistic tenets in architectural history and design. Style may be meaningful to increase one's understanding of high-style architectural achievements, but far less useful in tracing the continuity of a theme such as the way common people have established home and place (with the built and natural environment) throughout the ages. The Medieval townhouse, because it transcends many styles and is alive and well today, needs a more appropriate and effective classification. The next three constructs will attempt to formulate a more useful and effective design paradigm.

Some scholars would classify the Medieval townhouse as a "timeless" way to build or as a vernacular tradition (Fig. 13). They are correct since the townhouse has evolved from local people, traditions, climate and regional materials. Matthews [14] is successful in using a model of traditions to give greater meaning to history: vernacular, high style (the periods and styles of architecture), speculative (developed for profit, i.e., suburbia) and participation (developed in a collaborative partnership between the public, users and professionals). Not to diminish the above clarity, Matthews concludes with a fifth tradition - conservation or sustainability (stewardship of our built, human and natural resources). The classifications of traditions are useful because they transcend the historic styles and form a useful design paradigm. Sustainability is a critical and hopefully fast becoming an established tradition of 21 st century.

There is a growing number of effective built environments that are based upon a more ecological function and form, cause and effect principles and patterns. In general, this work deals with carefully analysing successful, livable human-environmental patterns and then defining effective design principles. Jacob [10], Newman [11] and Alexander [15, 16] are important proponents of this design paradigm. This approach is a more useful method to understand the lessons set forth in this study of the acre and the Medieval townscape. Alexander states it is "a timeless way to build" that does not fit a static label, a "quality without a name." It is a built environment that is rich in definable patterns of healthy and sustainable human-environmental relationships that can be adapted to various contemporary urban settings (Fig. 14).

Exploring the dynamic and ecological qualities of the townhouse, one can appreciate a deeper, evolutionary understanding of the livable patterns of successful human-environmental relationships, which are complementary to both architecture and urbanism (Figs 15 \& 16). Studying and creating healthy (or avoiding unhealthy) patterns of human-environmental relationships is generally defined as an ecological or ecodynamic paradigm. This proposed pattern-based ecological model is a useful method for teaching and practicing architecture, especially when dealing with sensitive residential and community developments. This is an adaptive, reality-based paradigm that expresses and celebrates the unique qualities and interrelated patterns of home, place and environment. An excellent example of a bioregional, ecological development is fostered by One Planet Living

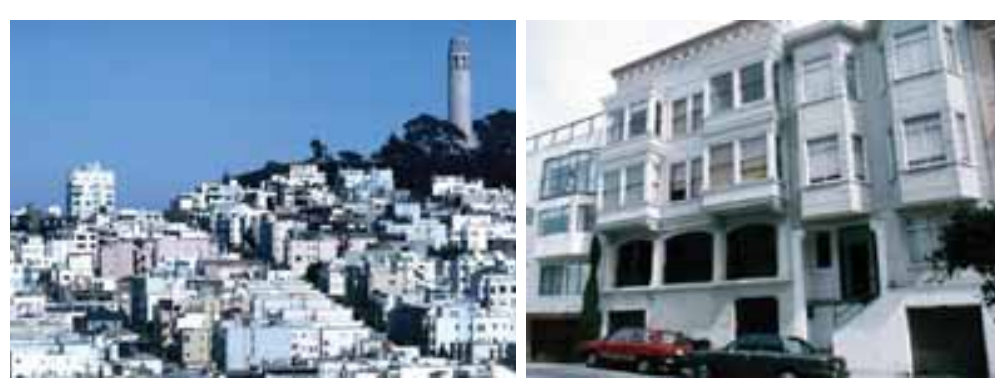

Figure 13: Vernacular town housing in San Francisco, USA. 

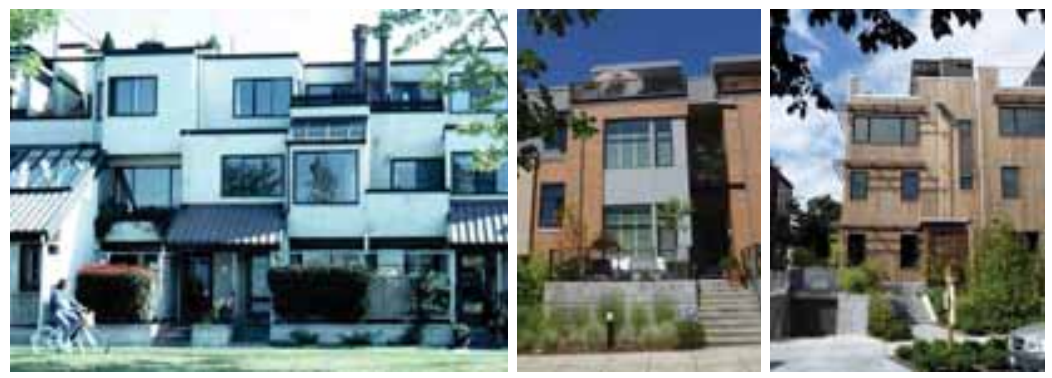

Figure 14: Contemporary townhouses in Vancouver, Canada, Portland and Seattle (LEED Platinum), USA.
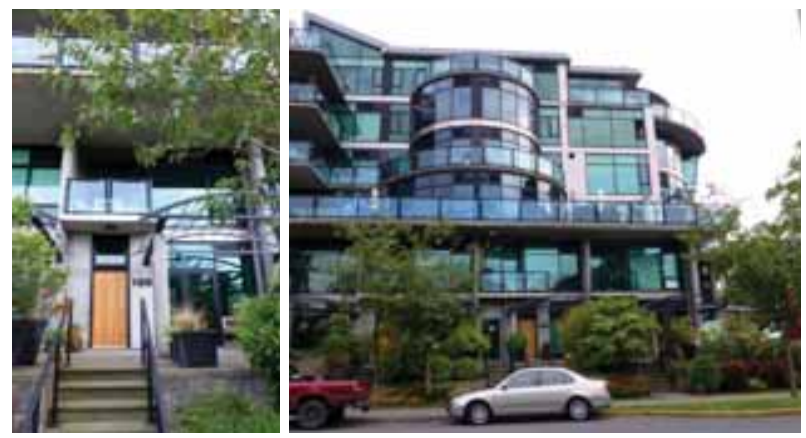

Figure 15: Contemporary town housing built at street level for effective surveillance with apartments above, Victoria, Canada.
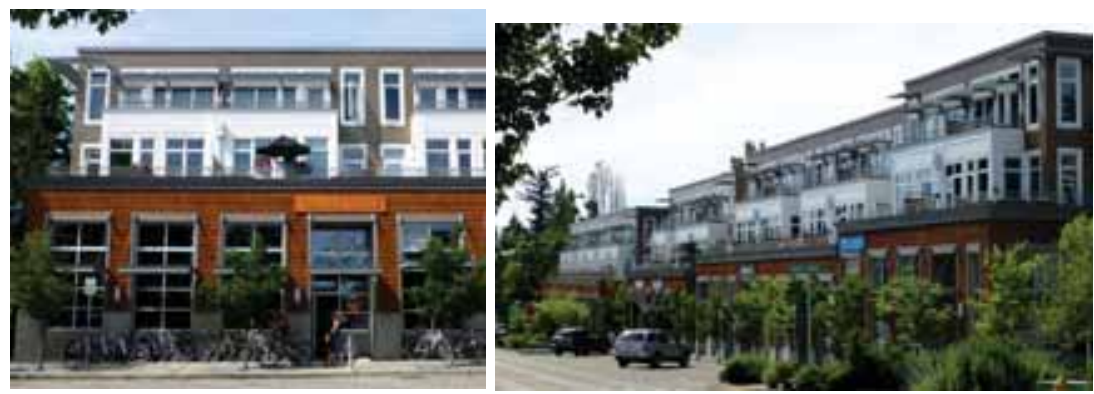

Figure 16: Contemporary town housing built above commercial development at ground level, Bainbridge Island, USA.

Communities (OPL) $[17,18]$. OPL communities are based upon equitable sharing of one earth as defined by one's ecological footprint [19]. Each approved development must satisfy a comprehensive set of 10 criteria for all aspects of human-environmental sustainability. OPL's housing and community approach is compatible with the patterns and principles of the townhouse (Fig. 17).

Today, societies face a very critical time in human and planetary evolution. In-depth studies of building prototypes, such as the townhouse, can lead the way to a more integrated and ecological 

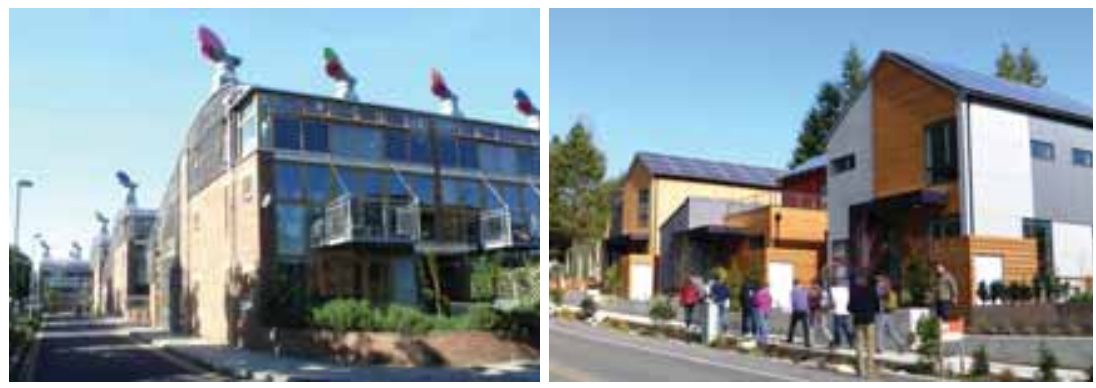

Figure 17: One Planet Living communities: BedZED, Wallingford, UK and Grow, Bainbridge Island, USA (narrow lots).

paradigm for the effective design and planning of a sustainable built environment. Housing and its interrelationship with community and the natural environment are a critical part of a truly sustainable world.

\section{REFERENCES}

[1] Rasmussen, S., London, The Unique City, MIT: Cambridge, MA, 1985.

[2] Howard, E., Garden Cities of To-Morrow (republished in 1965), MIT: Cambridge, MA,1898.

[3] RERC (Real Estate Research Corporation), The Cost of Sprawl, U.S. Government Printing Office, 1974.

[4] Buttner, H., Townhouses of Europe, Antique Collectors Club: London, 1983.

[5] Hoskins, W., The Making of the English Landscape, Pengin: London, 1955.

[6] Muir, R., History from the Air, M. Joseph Limited. Photographs from The University of Cambridge, 1983 (Collection of Air Photographs), pp. 99-105, 1983.

[7] Lynch, K., Site Planning, MIT: Cambridge, MA, 1962.

[8] Cullen, G., The Concise Townscape, Van Nostrand Reinhold: New York, 1961.

[9] Lloyd, D., The Making of English Towns, Victor Gollancz Ltd: London, 1984.

[10] Jacobs, J., The Death and Life of Great American Cities, Random House: New York, 1961.

[11] Newman, O., Defensible Space, Collier: New York, 1973.

[12] Essex County Council. Design Guide for Residential Areas, County Council of Essex: Chelmsford, 1973.

[13] https://www.gov.uk/government/topics/planning-and-building.

[14] Matthew, H. The Four Traditions in the Built Environment (Chapter in The Built Environment, McClure and Bartuska, Eds.), Wiley: Hoboken, NJ, 2007.

[15] Alexander, C. et al., A Pattern Language, Oxford: New York, 1977.

[16] Alexander, C. et al., The Timeless Way, Oxford: New York, 1975.

[17] Bioregional Development Group, BedZED: Wallington, UK. Available at http://www.oneplanet living.net/what-is-one-planet-living/.

[18] Grow Community, Bainbridge Island: Washington, USA. Available at http://growbainbridge. com/the-experience/one-planet-living/.

[19] My Ecological Footprint (many sources). Available at http://www.myfootprint.org/. 